\author{
Justyna Matys ${ }^{1}$
}

\title{
Nowa ustawa o kształtowaniu ustroju rolnego - uwagi do projektu Polskiego Stronnictwa Ludowego
}

Z dniem 1 maja 2016 r. minie 12 lat od przystąpienia Polski do Unii Europejskiej. W obrocie nieruchomościami rolnymi jest to bardzo istotna, szczególna data. Jej upływ oznacza koniec terminu przejściowego na zakup nieruchomości rolnych i leśnych położonych w Polsce przez obywateli państw - stron umowy o Europejskim Obszarze Gospodarczym albo Konfederacji Szwajcarskiej, jaki został wynegocjowany i zapisany w załączniku nr 12 Traktatu Akcesyjnego. ${ }^{2}$ Od tego momentu obywatele państw członkowskich UE oraz Szwajcarii będą mogli na równych zasadach jak obywatele polscy nabywać własność nieruchomości rolnych położonych w Polsce. Ponownie narasta wśród polskich rolników niepokój i obawa, że nieruchomości położone w Polsce staną się przedmiotem wzmożonego zainteresowania nabywców z innych krajów Unii Europejskiej. Obecnie obowiązująca ustawa z dnia 11 kwietnia 2003 r., o kształtowaniu ustroju rolnego, ${ }^{3}$ nie daje gwarancji w pełni skutecznego przeciwdziałania możliwości nabywania własności nieruchomości rolnych przez obywateli innych państw. Stąd też pojawia się postulat wzmocnienia ochrony, także przed spekulacyjnym wykupywaniem nieruchomości rolnych przez obywateli polskich, którzy traktują je jak lokatę kapitału i nie gwarantują ich rolniczego wykorzystania.

Do Sejmu wpłynęły dwa projekty poselskie dotyczące zmian w sferze gospodarowania nieruchomościami rolnymi. Pierwszy z nich - projekt Prawa i Sprawiedliwości - obejmuje nowelizację dotychczasowej ustawy o kształtowaniu ustroju rolnego, ${ }^{4}$ bazując na dotychczas istniejących instrumentach kontroli obrotu, jakim jest prawo pierwokupu i prawo wykupu (nazywane też prawem nabycia - art. 4 ustawy o kształtowaniu ustroju rolnego). Zostało przewidziane bardzo istotne ograniczenie w rozporządzaniu nieruchomością, wątpliwe pod względem zgodności z Konstytucją. Mianowicie przez 10 lat od dnia nabycia, rolnik będzie zobowiązany osobiście

\footnotetext{
Uniwersytet w Białymstoku.

Traktat Akcesyjny podpisany w Atenach dnia 16 kwietnia 2003 r., Dz.U. Nr 90, poz. 864 ze zm.

Tekst jednolity Dz.U. z 2012 r., poz. 803.

Druk sejmowy nr 1659. PiS złożyło również projekt nowelizacji ustawy o gospodarowaniu nieruchomościami rolnymi Skarbu Państwa, druk sejmowy nr 1925.
} 
prowadzić gospodarstwo rolne, do którego zostanie włączona nabywana nieruchomość. W tym czasie nie będzie też można zbyć, obciążyć, ani oddać nabytej nieruchomości w użytkowanie innym podmiotom. Postanowienie podobnej treści jest zawarte w projekcie nowej ustawy o kształtowaniu ustroju rolnego autorstwa PSL w części zmieniającej ustawę o gospodarowaniu nieruchomościami rolnymi Skarbu Państwa. Pomysł PSL zakłada nieco mniejsze obostrzenia i odnosi je do nieruchomości nabytej z Zasobu. Obejmuje zakaz przenoszenia własności nieruchomości przez 10 lat od dnia nabycia (wyjątkiem jest zbycie na rzecz podmiotów wskazanych w art. 12 ust. 2 pkt 1,2 i 5 projektu) oraz wymóg osobistego prowadzenia na niej działalności rolniczej w tym okresie. Propozycja PSL przewiduje dodatkowo karę pieniężną za niedochowanie projektowanych wymogów.

Propozycje PiS i PSL są nieprzemyślane od strony praktyki prowadzenia działalności rolniczej, ograniczenia sięgają zbyt głęboko w istotę prawa własności, prawo rozporządzania własnością, co jest sprzeczne z Konstytucją. Zakaz obciążania nieruchomości obejmuje zakaz ustanawiania na niej służebności gruntowych i osobistych, także służebności przesyłu, nieruchomość ta nie będzie mogła być przedmiotem umowy dożywocia. Wyłączone jest ustanowienie na niej hipoteki. ${ }^{5}$ Projektowane przepisy zarówno PiS, jak i PSL odnoszące się do ograniczeń zbywaniu, obciążaniu nabytej nieruchomości w proponowanym brzmieniu nie powinny zostać przyjęte.

Projekt ustawy o kształtowaniu ustroju rolnego opracowany przez PSL przewiduje równocześnie zmiany $\mathrm{w}$ innych ustawach. ${ }^{6}$ Oprócz znanych i funkcjonujących na podstawie obecnej ustawy z 11 kwietnia 2003 r. mechanizmów kontroli obrotu nieruchomościami rolnymi w postaci prawa pierwokupu i wykupu przysługującego Agencji Nieruchomości Rolnych, działającej na rzecz Skarbu Państwa, projekt ustawy zakłada jeszcze bardziej intensywny nadzór nabycia nieruchomości rolnych przez Agencję. Argumentem jest to, że aktualne instrumenty nie realizują w pełni celów kształtowania ustroju rolnego; szczególny niepokój wśród projektodawców wzbudza systematyczne i stałe zmniejszanie się powierzchni użytków rolnych w Polsce, widoczne jest rozdrobnienie gospodarstw rolnych, a jedną z przyczyn są nieracjonalne podziały gospodarstw. ${ }^{7}$ Aby skuteczniej przeciwdziałać tym trendom, PSL w projekcie ustawy o kształtowaniu ustroju rolnego zawarło nowe mechanizmy, które w założeniu efektywniej niż dotychczasowe mają oddziaływać

W projekcie PSL zostało zawarte postanowienie, że Agencja może wyrazić pisemną zgodę na ustanowienie hipoteki na nieruchomości nabytej z Zasobu, wówczas kara pieniężna nie będzie stosowana.

$6 \quad W$ ustawie $z$ dnia 19 października 1991 r. o gospodarowaniu nieruchomościami rolnymi Skarbu Państwa, tekst jednolity Dz.U. z 2012 r., poz. 1187 ze zm., ustawie z dnia 3 lutego 1995 r. o ochronie gruntów rolnych i leśnych, tekst jednolity Dz.U. z 2013 r., poz. 1205 ze zm., ustawie z dnia 21 sierpnia 1997 r. o gospodarce nieruchomościami, tekst jednolity Dz.U. z 2010 r. Nr 102, poz. 651 ze zm., ustawie z dnia 27 marca 2003 r. o planowaniu i zagospodarowaniu przestrzennym, tekst jednolity Dz.U. z 2012 r., poz. 647 ze zm., ustawie z dnia 28 lipca 2005 r. o kosztach sądowych, tekst jednolity Dz.U. z 2010 r. Nr 90, poz. 594 ze zm. 
na strukturę agrarną państwa. Nie wydaje się jednak, aby proponowane środki miały w sposób znaczący polepszyć tę strukturę. Przede wszystkim przedstawiciele nauki prawa rolnego w niedługim czasie po wejściu w życie obecnie obowiązującej ustawy o kształtowaniu ustroju rolnego wskazywali na jej mankamenty oraz znikomą przydatność w realizacji celów zakreślonych w jej art. $1{ }^{8} \mathrm{~W}$ szczególności Prof. A. Lichorowicz zgłosił szereg krytycznych uwag odnoszących się do rozwiązań zawartych w obecnej ustawie o kształtowaniu ustroju rolnego, w tym tak podstawowych kwestii, jak definicja gospodarstwa rodzinnego. ${ }^{9}$ Część zostało uwzględnionych w nowelizacji ustawy z dnia 6 maja 2010 r., ${ }^{10} \mathrm{w}$ zakresie odnoszącym się do kwalifikacji rolniczych oraz pracy w gospodarstwie. Nie zostały jednak usunięte najważniejsze niedociągnięcia ustawy: jej skuteczności w odniesieniu do poprawy struktury gruntowej rolnictwa, pojęcia gospodarstwa rodzinnego oraz rolnika indywidualnego, przedmiotowego zakresu prawa wykupu, uszczelnieniu występujących luk, umożliwiających obchodzenie ustawy przez cudzoziemców, nadmiernej roli oraz ingerencji Agencji Nieruchomości Rolnych w obrót nieruchomościami rolnymi oraz przede wszystkim wprowadzenia jednolitej regulacji, podobnego zakresu ingerencji i kontroli w obrocie intervivos, jak i mortis causa. Można było oczekiwać, że wskazane w piśmiennictwie braki będą usunięte w projektach nowej ustawy regulującej ustrój rolny. Niestety, tak się nie stało. Projekt PSL wykorzystuje dotychczasowe rozwiązania, w nieznacznym stopniu uwzględnia uwagi przedstawicieli doktryny, czyniąc to w odniesieniu do zagadnień o drugorzędnym charakterze, a proponowane nowe rozwiązania wywołują znaczące wątpliwości co do skuteczności oddziaływania na strukturę agrarną.

Zob. w szczególności A. Lichorowicz, Instrumenty oddziaływania na strukturę gruntową Polski w ustawie z dnia 11 kwietnia 2003 r. o kształtowaniu ustroju rolnego, KPP 2004, z. 2, s. 385 i n.; idem, Regulacja obrotu gruntami rolnymi według ustawy z 11 kwietnia 2003 r. na tle ustawodawstwa agrarnego Europy Zachodniej, „Przegląd Legislacyjny" 2004, nr 3, s. 11 i n.; S. Prutis, Kształtowanie ustroju rolnego - potrzeba nowej regulacji ustawowej, „Studia luridica Agraria” 2005, tom V, s. 168 i n.; E. Gniewek, Obowiązki notariusza w świetle współczesnych ograniczeń obrotu nieruchomościami rolnymi, [w:] E. Gniewek (red.), Zawieranie i wykonywanie umów. Wybrane zagadnienia, Acta Universitatis Wratislaviensis nr 26167, Wrocław 2004, s. 29 i n.; Z. Truszkiewicz, Przeniesienie własności nieruchomości rolnej w świetle ustawy o kształtowaniu ustroju rolnego, „Rejent” 2003, nr 9 (cz. I), s. 48 i n., nr 11 (cz. II), s. 113 i n.; L. Błądek, Niektóre rozważania na temat ustawy z dnia 11 kwietnia 2003 r. o kształtowaniu ustroju rolnego, „Rejent” 2003, nr 9, s. 140 i n.; D. Łobos-Kotowska, Ochrona gospodarstwa rodzinnego w procesie zbywania nieruchomości rolnych przez Agencję Nieruchomości, [w:] K. Skotnicki, K. Winiarski (red.), Własność i jej ograniczenia w prawie polskim, Częstochowa 2004, s. 133; T. Kurowska, Ochrona gospodarstwa rodzinnego - uwagi de lege lata i de lege ferenda, „Studia luridica Agraria” 2010, tom VII, s. 21 i n.; E. Klat-Górska, Ograniczenia w nabywaniu własności nieruchomości rolnych według ustawy o kształtowaniu ustroju rolnego (cz. II), „Rejent” 2004, nr 6, s. 86. Wskazuje się, że ustawa o kształtowaniu ustroju rolnego jest niezgodna z prawem Unii Europejskiej, zob. M. Mataczyński, W kwestii zgodności ustawy z dnia 11 kwietnia 2003 r. o kształtowaniu ustroju rolnego z prawem europejskim w świetle orzecznictwa Europejskiego Trybunału Sprawiedliwości, „Rejent” 2004, nr 9, s. 73 i n. Jedynie R. Sztyk, stwierdza, że ustawa o kształtowaniu ustroju rolnego w sposób kompleksowy urzeczywistnia zasadę zawartą w art. 23 Konstytucji, zob. R. Sztyk, Podstawowe zasady kształtowania ustroju rolnego, „Rejent” 2003, nr 9, s. 21. Zob. też wyrok TK z dnia 18 marca 2010 r., sygn. K 8/08, OTK -A 2010, nr 3, poz. 23, w którym Trybunał orzekł, że art. 4 ustawy o kształtowaniu ustroju rolnego jest zgodny z Konstytucją.

9 A. Lichorowicz, Instrumenty oddziaływania..., op. cit., s. 399 i n.

10 Ustawa o zmianie ustawy o kształtowaniu ustroju rolnego, Dz.U. Nr 110, poz. 725. 
Projekt zakłada utworzenie rejestru nieruchomości rolnych, który ma być prowadzony w systemie elektronicznym przez Agencję Nieruchomości Rolnych (proponowany art. 5). Według projektodawców celem rejestru będzie przeciwdziałanie nieformalnemu obrotowi nieruchomościami rolnymi. W doktrynie było wskazywane, że to nadmierny rygoryzm oraz zbyt daleko posunięta kontrola obrotu rolnego sprawia, że rolnicy obchodzą przepisy, co skutkuje zagrożeniem dla pewności i bezpieczeństwa obrotu. ${ }^{11}$ Jak wskazywał Prof. A. Stelmachowski, miało to miejsce w przeszłości w obrocie ziemią, gdzie nazbyt rozbudowane wymogi skutkowały obrotem nieformalnym, mimo nieważnych transakcji następowała zmiana posiadania. ${ }^{12}$ Niewątpliwie projekt ustawy zakłada bardzo daleko posuniętą kontrolę obrotu w celu przeciwdziałania nabywaniu nieruchomości rolnych przez cudzoziemców. Skutki uszczelniania obrotu będą bardzo mocno odczuwane przez rolników. Uchwalenie projektu ustawy spowoduje, że każdy podmiot, w którego posiadaniu jest nieruchomość rolna w ciągu roku od wejścia w życie ustawy będzie zobowiązany do złożenia wniosku o wpis do rejestru. Zmiana posiadania nieruchomości lub jej części będzie wymagała złożenia odpowiedniego wniosku o wpis w ciągu 14 dni od jej objęcia w posiadanie. Projektodawcy posługują się ogólnym sformułowaniem posiadacza, nie odnosząc tego wyłącznie do posiadania samoistnego. Obowiązek złożenia wniosku dotyczy, jak z tego wynika, także posiadacza zależnego, aczkolwiek należy pamiętać o treści art. $337 \mathrm{kc} .{ }^{13}$ Do wniosku posiadacz będzie dołączał kopie dokumentów uzasadniających wpis, jego zmianę lub wykreślenie z rejestru. Projektodawca nie doprecyzował, że mają to być kopie poświadczone za zgodność z oryginałem, co sugeruje, że wystarczy kserokopia dokumentu. Nie wydaje się to jednak słuszne, uwzględniając skutki prawne takiego wpisu (początek biegu terminu zasiedzenia art. 19 projektu) oraz możliwość fałszerstwa dokumentu, na podstawie którego będzie dokonywany wpis.

W związku z funkcjonowaniem nowego rejestru kolejny obowiązek informacyjny zostanie też nałożony na notariuszy. Będą oni zawiadamiać Agencję o zawartych umowach przenoszących własność lub użytkowanie wieczyste nieruchomości rolnych albo ich części. Mówi o tym art. 7 ust. 1 projektu, wskazując, że zawiadomienie to będzie następowało w formie elektronicznej przez przesłanie kopii odpisu aktu notarialnego. Projektowany przepis wywołuje wątpliwości. Przede wszystkim przeniesienie prawa użytkowania wieczystego nie następuje $\mathrm{z}$ chwilą zawarcia umowy w formie aktu notarialnego - podpisania aktu przez stawających i przez notariusza, konieczny jest wpis do księgi wieczystej, który ma charakter konstytu- 
tywny. Dopiero z chwilą wpisu następuje przeniesienie użytkowania wieczystego ${ }^{14}$ (art. 27 ustawy o gospodarce nieruchomościami). Odmowa wpisu przez sąd wieczystoksięgowy oznacza, że nie dojdzie do przeniesienia prawa użytkowania wieczystego na nabywcę. Natomiast Agencja Nieruchomości Rolnych po zawiadomieniu przez notariusza dokona z urzędu zmiany w rejestrze (art. 7 ust. 2 projektu ustawy). Spowoduje to niezgodność zapisu w rejestrze z rzeczywistym stanem prawnym. Należy postulować o wykreślenie z projektu ustawy zapisu odnoszącego się do obowiązku notariusza przesyłania kopii odpisu umowy przeniesienia prawa użytkowania wieczystego. Podmiotem zobowiązanym do złożenia odpowiedniego wniosku o zmianę wpisu w rejestrze nieruchomości rolnych powinien być nabywca prawa użytkowania wieczystego nieruchomości, zaś jako podstawę wpisu trzeba wskazać prawomocne postanowienie sądu, wydziału ksiąg wieczystych o dokonanym wpisie prawa użytkowania wieczystego.

Kompletność oraz pewność informacji gromadzonych w rejestrze nieruchomości rolnych wymagałaby, aby notariusz przesyłał do rejestru także odpowiednią informację o obciążeniu nieruchomości rolnej ograniczonymi prawami rzeczowymi oraz dzierżawą. W szczególności długotrwałe prawo użytkowania czy umowa dzierżawy stwarza możliwość prowadzenia działalności rolniczej na terenie Polski przez cudzoziemców. Aby zabezpieczyć pewność obrotu należałoby obowiązkiem złożenia wniosku obciążyć także notariusza, który na żądanie stron umowy sporządzałby odpowiednią czynność notarialną, a której przedmiotem byłaby nieruchomość rolna. Trzeba pamiętać, że zgodnie z projektem, umowa dzierżawy ma być zawarta w formie pisemnej pod rygorem nieważności, a jej przedmiotem może być wyłącznie taka nieruchomość rolna lub jej część, która została wpisana do rejestru, a wydzierżawiający jest w nim wpisany jako jej właściciel lub posiadacz.

Uwagę zwraca bardzo nieprecyzyjny zapis dotyczący sposobu przesłania przez notariusza zawiadomienia do Agencji w postaci kopii odpisu aktu notarialnego umowy, na podstawie której została przeniesiona własność lub użytkowanie wieczyste nieruchomości rolnej lub jej części. Projektodawca stwierdza, że ma to nastąpić „drogą elektroniczną” (art. 7 ust. 1). Oznacza to, że wiadomość wysłana pocztą elektroniczną z dołączonym załącznikiem kopii odpisu aktu notarialnego będzie odpowiednim sposobem zawiadomienia. Jednak należy zgłosić zastrzeżenia w kwestii przesyłania przez notariuszy jakichkolwiek informacji, dokumentów zawierających dane stron czynności notarialnej oraz treści tej czynności w postaci, jaka nie będzie należycie zabezpieczona przed możliwym ujawnieniem wiadomości w nich

14 Sąd Najwyższy w wyrok z dnia 5 lipca 2001 r., sygn.II CKN 1220/00, OSP 2002, nr 9, poz. 123 słusznie stwierdza, że nabywca użytkowania wieczystego w drodze umowy nie może rozporządzać tym prawem przed wpisaniem go w księdze wieczystej jako użytkownika wieczystego. Zob. też uchwałę SN z dnia 21 maja 2002 r., sygn. III CZP 29/02, OSN 2003, nr 6, poz. 76, wyrok SN z dnia 8 lipca 2005 r., sygn.II CK 208/05, Lex nr 603856, postanowienie SN z dnia 27 października 2006 r., sygn.I CSK 184/06, Lex nr 398439. 
zawartych osobom trzecim. Zgodnie z art. 18 ust. 1 ustawy Prawo o notariacie ${ }^{15}$ notariusz jest obowiązany zachować tajemnicę, co do okoliczności sprawy, o których dowiedział się w związku z dokonywaną czynnością notarialną. ${ }^{16}$ Wysyłanie wiadomości zwykłą pocztą internetową bez odpowiedniego zabezpieczenia systemu stanowi zagrożenie naruszenia tajemnicy notarialnej. Notariusze zgłaszali swoje zastrzeżenia i obawy w związku z udostępnianiem danych na podstawie przepisów ustawy o przeciwdziałaniu praniu pieniędzy oraz finansowaniu terroryzmu. ${ }^{17}$ Dane te są przesyłane w postaci elektronicznej z wykorzystaniem bezpiecznego podpisu elektronicznego. W przypadku rejestru nieruchomości projektodawca nie wspomina o wykorzystaniu tej bezpieczniejszej formy.

W treści projektowanego art. 7 ust. 1 nie został wskazany termin, w jakim notariusz jest zobowiązany przesłać kopię odpisu aktu notarialnego Agencji Nieruchomości Rolnych. Można przyjąć w drodze analogii, że powinien uczynić to w ciągu 14 dni od zawarcia umowy przenoszącej własność, powołując się na adekwatny obowiązek właściciela lub posiadacza określony w art. 8 ust. 1 projektu. Termin 14-dniowy przesłania odpisu aktu notarialnego wiąże notariusza na podst. art. 23 ust. 5 ustawy prawo geodezyjne i kartograficzne, ${ }^{18} \mathrm{w}$ przypadku gdy konieczne jest dokonanie zmian w ewidencji gruntów i budynków.

Zasadne jest zgłoszenie postulatu, aby zamiast odpisu aktu notarialnego (kopii odpisu aktu notarialnego), który stanowi powtórzenie treści oryginału aktu notarialnego, notariusz przesyłał jedynie wyciąg aktu, zawierający informacje niezbędne do prowadzenia rejestru nieruchomości rolnych. Przesłanie w formie odpisu treści całego aktu notarialnego, zawierającego także niejednokrotnie oświadczenia stron o stosunkach osobistych i rodzinnych stron jest zbędne i stanowi zagrożenie naruszenia prawa do prywatności stron czynności notarialnej przez osoby obsługujące przyszły rejestr. Takie propozycje zostały już zgłoszone w odniesieniu do danych przekazywanych przez notariuszy do poszczególnych organów oraz instytucji, którym notariusz jest zobowiązany przesyłać wypisy aktów notarialnych. Argumentem jest przekroczenie tajemnicy notarialnej. ${ }^{19}$

W przypadku, gdy zbywcę reprezentuje Agencja, czyli przy zawieraniu umowy sprzedaży nieruchomości rolnej na podst. art. 12 projektu, notariusz byłby zwolniony z obowiązku zawiadamiania Agencji. Brak jest tożsamego postanowienia odnoszącego się do sytuacji, gdy nabywcą nieruchomości rolnej jest Agencja, wykonująca prawo nabycia z art. 15 ust. 4 projektu (ma zastąpić prawo pierwokupu z art. 3

15 Ustawa z dnia 14 lutego 1991 r., tekst jednolity Dz.U. z 2014 r., poz. 164 ze zm.

16 Zob. szerzej W. Boć, Status prawny notariusza, Łódź 2010, s. 152 i n.

17 Ustawa z dnia 16 listopada 2000 r., tekst jednolity Dz.U. z 2014 r., poz. 455.

18 Ustawa z dnia 17 maja 1989 r., tekst jednolity Dz.U. z 2010 r. Nr 193, poz. 1287 ze zm.

19 W. Boć, Status prawny..., op. cit., s. 162 i lit. tam powołana, A. Redelbach, Tajemnica zawodowa notariusza w Rzeczypospolitej Polskiej w świetle zasady poszanowania życia prywatnego, „Rejent” 1999, nr 6-7, s. 33. 
ust. 4 obecnej ustawy o kształtowaniu ustroju rolnego) oraz prawo wykupu z art. 17 ust. 1 projektu (art. 4 ust. 1 obecnej ustawy).

Oprócz wskazanych usterek i niedociągnięć związanych z przekazywaniem informacji do planowanego rejestru nieruchomości, wątpliwości wzbudza już sam sens tworzenia kolejnej bazy danych o nieruchomościach obok ksiąg wieczystych i ewidencji gruntów i budynków (w przyszłości kataster nieruchomości). Zarówno księgi wieczyste, jak i ewidencja zawierają informacje, jakie będą gromadzone w planowanym rejestrze,$^{20}$ można przypuszczać, że są one nawet bardziej szczegółowe. O ile informacje gromadzone w księgach mogą nie być aktualne (dotyczy to w szczególności informacji z działu I-O obejmującego powierzchnię, położenie działek) to dane w ewidencji, które służą ustaleniu stanu faktycznego, pełnią funkcję informacyjną, stanowią podstawę wpisu i zmian wpisu nieruchomości do księgi wieczystej są aktualne. W związku z tym należy zastanowić się i rozważyć wykorzystanie ewidencji gruntów i budynków z ewentualną niezbędną modyfikacją i zmianą dostosowującą gromadzone w ewidencji informacje do potrzeb Agencji Nieruchomości Rolnych niż tworzenie nowej bazy danych. Konieczne jest zmniejszanie biurokratyzacji, mnożenia i powielania wymagań dotyczących składania dokumentów zawierających takie same informacje w kolejnych instytucjach państwowych. Agencja Nieruchomości Rolnych jest instytucją o wybitnym charakterze politycznym, dostęp do tak ważnych informacji przez osoby o nadaniu partyjnym może wzbudzać obawy. Rejestr to także koszty finansowe związane z jego utworzeniem, stworzeniem odpowiedniego oprogramowania komputerowego, zabezpieczenia przed dostępem oraz dokonywaniem w nim zmian i wpisów przez osoby trzecie, to także wydatki związane z jego funkcjonowaniem i aktualizacją danych. Również ten aspekt należy wziąć pod uwagę, gdyż pomnaża to koszty funkcjonowania Agencji Nieruchomości Rolnych. Poruszając zagadnienie zasadności tworzenia rejestru uwzględnić należy funkcje, jakie projektodawca wiąże z jego działaniem. Na podstawie danych gromadzonych w rejestrze będą wydawane przez Agencję lub Dyrektora oddziału zaświadczenia niezbędne do stwierdzenia, że dana osoba jest rolnikiem indywidualnym (art. 23 ust. 1 oraz projektu). Jest to zaświadczenie o osobistym prowadzeniu gospodarstwa rolnego oraz zaświadczenie, potwierdzające powierzchnie posiadanych użytków rolnych. Co roku również będą na stronie internetowej Agencji publikowane informacje o średnich cenach sprzedaży nieruchomości rolnych w każdym powiecie w poprzednim roku (art. 10 projektu). Informacje te są gromadzone i dostępne w ewidencji gruntów i budynków, podobnie jak informacje niezbędne do wydania przez Dyrektora oddziału decyzji wskazanych w art. 11 ust. 5 uszczegółowienie będzie zawarte w rozporządzeniu wydanym przez ministra właściwego do spraw rozwoju wsi na podst. art. 9 ust. 2 projektu ustawy. 
pkt 1 i $2 .{ }^{21}$ Uwagę zwraca postanowienie art. 11 ust. 5 pkt 3, na podstawie którego Dyrektor wydaje decyzję potwierdzającą, że zbywana nieruchomość lub jej część ma zapewniony dostęp do drogi publicznej. Konieczne jest tu sprawdzenie mapy ewidencyjnej dostępnej w ewidencji, ukazującej położenie nieruchomości w przestrzeni.

Z funkcjonowaniem rejestru projektodawca połączył bardzo istotny skutek prawny, modyfikujący zasadę obowiązującą na podstawie przepisów Kodeksu cywilnego. Mianowicie od daty wpisu w rejestrze, a nie jak to jest w art. $172 \mathrm{kc}$. od daty objęcia nieruchomości w posiadanie, liczony jest termin wymagany do stwierdzenia zasiedzenia nieruchomości. W uzasadnieniu projektu zostało stwierdzone, że wymóg wpisu ma zapobiegać obrotowi nieformalnemu nieruchomości. Do rejestru, zgodnie z projektem, ma być wpisany podmiot, który wszedł w posiadanie nieruchomości, zatem zarówno właściciel (który będzie posiadaczem samoistnym), jak i posiadacz zależny (przy czym posiadanie zależne nie prowadzi do zasiedzenia nieruchomości). Podstawą wpisu jest wniosek wraz z dołączonymi do niego kopiami dokumentów m.in. dotyczącymi podstawy władania nieruchomością. Zatem, żeby zostać wpisanym do rejestru należy wykazać tytuł prawny do nieruchomości, w konsekwencji bez ważnego dokumentu potwierdzającego podstawę władania nieruchomością nie będzie można uzyskać wpisu do rejestru.

Przesłanką zasiedzenia jest posiadanie samoistne oraz upływ odpowiedniego czasu, którego długość jest determinowana dobrą lub złą wiarą posiadacza. Nie jest możliwe stwierdzenie zasiedzenia, gdy nieruchomość znajduje się we władaniu posiadacza zależnego. $\mathrm{W}$ istocie art. 19 projektu ma za zadanie wyeliminowanie możliwości zasiedzenia nieruchomości rolnej przez cudzoziemców, którzy objęli nieruchomość w posiadanie na podstawie umów nieformalnych. Teoretycznie jest możliwe, jednak w praktyce wątpliwe, aby cudzoziemiec objął nieruchomość w posiadanie i był posiadaczem samoistnym na podstawie umowy sprzedaży bez dochowania formy aktu notarialnego, zatem umowy nieważnej. Cudzoziemiec podejmuje bowiem ryzyko, że po kilku latach zbywca wystąpi z roszczeniem windykacyjnym. Cudzoziemiec może mieć w takiej sytuacji problem z uzyskaniem zwrotu ceny, jaką zapłacił za nieruchomość.

W doktrynie A. Stelmachowski podkreślał funkcję posiadania jako korektury własności, ${ }^{22}$ wskazywał też na funkcję zasiedzenia, jaką jest dostosowanie stanu prawnego do układu stosunków faktycznych. ${ }^{23}$ Uzależnienie rozpoczęcia biegu terminu zasiedzenia od wpisu do rejestru powoduje, że wpis nie stanowi jedynie po- 
twierdzenia stanu prawnego, ale zawiera pewne elementy o charakterze konstytutywnym.

Niektóre ze zgłoszonych w projekcie ustawy o kształtowaniu ustroju rolnego rozwiązań wywołują wątpliwości co do ich zgodności z 21 Konstytucji i art. 64 ust. 3 Konstytucji. Ingerują one w istotę własności, ograniczają klasyczną triadę uprawnień właściciela, wywodzącą się z prawa rzymskiego. Prawo własności wyraża najszerszy zakres stosunku podmiotu do dóbr materialnych, nie jest to jednak prawo stanowiące absolutny monopol właściciela. ${ }^{24}$ Może podlegać ograniczeniom, których zakres i forma zostały określone art. 64 ust. 3 Konstytucji. Przepis ten stwierdza, że ograniczenia prawa własności nie mogą naruszać istoty tego prawa. Trybunał Konstytucyjny wskazywał co stanowi istotę prawa własności, której naruszenie nie jest dopuszczalne. W wyroku z dnia 25 maja 1999 r. stwierdził, że ograniczenia nie mogą niweczyć podstawowych uprawnień składających się na treść prawa własności. Trybunał zaznaczył, że podstawowym uprawnieniem właściciela jest rozporządzanie rzeczą, co oznacza możliwość wyzbycia się własności i obciążenia rzeczy. Jest to trzon prawa własności. ${ }^{25}$ Projekt ustawy narusza istotę własności, ograniczając prawo właściciela nieruchomości rolnej do rozporządzania nią. W szczególności jest to widoczne w przepisach, które nakazują sprzedaż nieruchomości rolnej lub jej części za pośrednictwem Agencji Nieruchomości Rolnych oraz planowanych zmianach w ustawie o gospodarowaniu nieruchomościami rolnymi Skarbu Państwa, dokonywanych równocześnie wraz z projektem ustawy o kształtowaniu ustroju rolnego (dodany art. 29a).

Projekt PSL znacząco wzmacnia pozycję Agencji Nieruchomości Rolnych w obrocie nieruchomościami rolnymi, mimo że w piśmiennictwie prawa rolnego są krytyczne wypowiedzi odnoszące się do zadań powierzonych Agencji na podstawie obecnej ustawy. ${ }^{26}$ Przykładem dalszego rozszerzania kompetencji Agencji Nieruchomości Rolnych jest projektowane wprowadzenie obowiązkowego pośrednictwa Agencji przy umowie sprzedaży nieruchomości rolnej i to niezależnie od jej powierzchni. Na tle dotychczasowych przepisów, rola Agencji ogranicza się do kontroli obrotu. Jest ona informowana o zawartych umowach przenoszących własność nieruchomości rolnych; może ingerować w umowne nabycie nieruchomości, wykonując przysługujące jej prawo pierwokupu lub prawo wykupu. ${ }^{27}$ Projekt zakłada nie tylko aktywne uczestnictwo Agencji przy zawieraniu umowy sprzedaży; rola Agencji będzie zdecydowanie większa. Przede wszystkim będzie ona ustalała ze zbywcą cenę nieruchomości, przy czym będzie mogła zwrócić się w tej kwestii do sądu,

24 A. Stelmachowski, Zarys..., op. cit., s. 174.

25 SK 9/98, Dz.U. 1999 Nr 49, poz. 498, zob. także wyrok TK z dnia 12 stycznia 1999 r., P 2/98, Dz.U. z 1999 r. Nr 3 , poz. 30.

26 S. Prutis, Kształtowanie ustroju rolnego..., op. cit., s. 172, 182.

27 Prawo pierwokupu oraz prawo wykupu nie przysługuje w przypadkach wskazanych w ustawie. W praktyce wyłączenia dotyczą znaczącej liczby ogółu zawieranych umów. 
w przypadku gdy nie będzie można ze zbywcą ustalić sumy pieniężnej, a zaproponowana we wniosku o dokonanie sprzedaży za pośrednictwem Agencji cena będzie odbiegać o więcej niż $20 \%$ od kwot stanowiących średnią cenę sprzedaży nieruchomości w powiecie (z uwzględnieniem powierzchni i klasy użytków). Sposób ustalenia ceny, wpływ na jej wysokość Agencji, ograniczenie czy nawet odebranie w tak ważnym aspekcie wyłącznych uprawnień właściciela niewątpliwie wywoła uzasadnione protesty rolników.

Sprzedawca nie będzie uczestniczył w procedurze wyłonienia nabywcy, jest tu pozbawiony aktywnego wpływu, to również ingerencja w prawo właściciela, w rozporządzanie prawem własności. Osoby zainteresowane nabyciem nieruchomości będą przedstawiane Agencji przez właściwą miejscowo izbę rolniczą spośród rolników indywidualnych zamieszkałych na terenie gminy miejsca położenia sprzedawanej nieruchomości lub gminy sąsiedniej. W uzasadnieniu zostało stwierdzone, że „podyktowane jest to potrzebą racjonalizowania obrotu nieruchomościami oraz dążeniem do wspierania obrotu międzysąsiedzkiego". Projektodawca ponownie nie wsłuchał się w zgłaszane propozycje przedstawicieli nauki, ${ }^{28}$ nie sięgnął też do rozwiązań sprawdzonych w praktyce w innych państwach członkowskich Unii Europejskiej. ${ }^{29}$ Zakładany cel proponowanej ustawy, wskazany w art. 1 pkt 1 , czyli poprawa struktury obszarowej gospodarstw rolnych zostałby osiągnięty w szerszym wymiarze, gdyby zostało wprowadzone sąsiedzkie prawo pierwokupu. W sytuacji, gdy sprzedaż nieruchomości rolnej za pośrednictwem Agencji odbywa się w trybie przetargu, nabywcą jest ten podmiot, który zaoferuje wyższą cenę. Trudno tu dopatrzeć się wspierania obrotu sąsiedzkiego, gdy sąsiad zbywcy, aby polepszyć strukturę obszarową swego gospodarstwa będzie zmuszony zapłacić wyższą sumę pieniężną za nieruchomość, niż gdyby zostało ustanowione prawo pierwokupu z zapłatą ceny ustalonej ze sprzedającym. Co więcej, uzasadnione jest twierdzenie, że brak sąsiedzkiego prawa pierwokupu przy proponowanym trybie przetargowym sprzedaży nieruchomości zabezpiecza interesy Agencji, ponieważ na podstawie art. 16 ust. 4 projektu, gdy Agencja sprzeda nieruchomość za cenę wyższą niż ustalona, zatrzyma połowę nadwyżki. Proponowany art. 16 ust. 4 powinien zostać usunięty, będzie on mógł stanowić przyczynę nienależytego zabezpieczania interesów sprzedającego przez Agencję. W jej interesie będzie ustalenie ze sprzedającym jak najniższej ceny sprzedaży nieruchomości, nie zaś zabezpieczenie jego praw. Ustalona cena będzie obowiązywała także w sytuacji, gdy to Agencja złoży oświadczenie o nabyciu nieruchomości na podst. art. 15 ust. 4 projektu. W projekcie prawo pierwokupu przysługujące Agencji z art. 3 ust. 4 obecnej ustawy o kształtowaniu ustroju zostaje zastąpione wskazanym oświadczeniem o nabyciu nieruchomości za cenę 
określoną w pełnomocnictwie. Oświadczenie o nabyciu będzie mogło zostać złożone po udzieleniu Agencji pełnomocnictwa i powinno następować w formie aktu notarialnego ze względu na zapis w projekcie o odpowiednim stosowaniu przepisów $\mathrm{KC}$ o prawie pierwokupu. Umowa między Agencją a zbywcą będzie miała charakter umowy zobowiązująco-rozporządzającej, nie ma potrzeby zawierania wcześniejszej umowy warunkowej. Powinna ona zostać zawarta w ciągu miesiąca od złożenia oświadczenia. Konsekwencją zastosowania przepisów o pierwokupie będzie wyłącznie możliwość zbycia nieruchomości rolnej innemu podmiotowi niż Agencja.

W przypadku, gdy postępowanie nie doprowadzi do wyłonienia kandydata spośród rolników indywidualnych gminy miejsca położenia zbywanej nieruchomości lub gminy sąsiedniej, ani też Agencja nie złoży oświadczenia o nabyciu w trybie art. 15 ust. 4 projektu, wówczas Agencja będzie mogła złożyć sprzedawcy ofertę nabycia nieruchomości lub jej części, wskazując cenę nabycia. Zbywca nieruchomości będzie mógł ofertę przyjąć lub odmówić zawarcia umowy lub w ciągu roku od dnia, w którym Agencja poinformuje go o niewyłonieniu nabywcy zbyć nieruchomość bez pośrednictwa Agencji. Projekt ustawy zastrzega, że w sytuacji gdy zaproponowana w ofercie cena nie będzie niższa niż 50\% ceny określonej w pełnomocnictwie, zbywca z kolejnym wnioskiem o sprzedaż tej samej nieruchomości będzie mógł wystąpić dopiero po upływie roku od dnia otrzymania oferty.

Pośredniczenie przez Agencję w sprzedaży nieruchomości rolnej odbywa się na podstawie udzielonego przez rolnika pełnomocnictwa. Powinno ono zostać udzielone w formie aktu notarialnego.

Projekt zakłada, że pośrednictwo Agencji nie będzie stosowane, gdy w wyniku umowy sprzedaży własność nieruchomości rolnej zostanie przeniesiona m.in. na rzecz rolnika indywidualnego na powiększenie gospodarstwa rodzinnego, także osoby bliskiej zbywcy. W tych sytuacjach Agencja nie będzie też uprawniona do złożenia oświadczenia o nabyciu nieruchomości rolnej na podst. art. 15 ust. 4 projektu. Należy zauważyć, co było już wskazywane w doktrynie, że gdy zbycie następuje na rzecz osoby bliskiej, cel obecnej ustawy, a także zamierzony cel projektu ustawy nie będzie realizowany, ponieważ osoby bliskie nie muszą posiadać kwalifikacji rolniczych.

Widoczna jest niekonsekwencja projektodawcy. Z jednej strony zakłada się, że pośrednictwa Agencji nie stosuje się, gdy kupującym jest rolnik indywidualny i wówczas uprawnienie $\mathrm{z}$ art. 15 ust. 4 Agencji nie będzie przysługiwać. Z drugiej zaś strony, gdy to izba rolnicza poda wykaz rolników indywidualnych zainteresowanych nabyciem, Agencji będzie przysługiwać prawo nabycia, będzie mogła skutecznie zapobiec nabyciu nieruchomości przez te osoby. Jest to pewna niespójność.

Założeniem projektodawcy jest zapobieganie nabywaniu nieruchomości rolnych przez cudzoziemców, kolejnym jest ograniczenie nabywania nieruchomości 
rolnych przez osoby nieuprawnione, nabywające nieruchomości w innych celach niż prowadzenie produkcji rolnej. ${ }^{30}$ Stąd też planowane wprowadzenie nowych instrumentów kontroli obrotu, jednak projektowane rozwiązania są niejasne, niespójne, zakładają różne mechanizmy ingerencji w obrót w odniesieniu do osób posiadających status rolnika indywidualnego w rozumieniu projektu ustawy.

Projektodawca tworzy instrument wspierania młodych rolników, którzy nie ukończyli 40 lat, ponieważ o nabycie nieruchomości będą mogą ubiegać się także rolnicy indywidualni, którzy nie prowadzą jeszcze gospodarstwa rolnego przez wymagany okres 5 lat (art. 29 ust. 3bb ustawy o gospodarowaniu nieruchomościami rolnymi, który ma być dodany wprowadzoną ustawą o kształtowaniu ustroju rolnego). Będą oni mogli przystąpić do przetargu na nabycie nieruchomości także gdy pośredniczyć będzie Agencja.

Pośrednictwo Agencji przy sprzedaży nieruchomości rolnej będzie wymagane niezależnie od powierzchni tej nieruchomości. Projektodawca nie określa minimalnej powierzchni, co jest zmianą w porównaniu do obecnego stanu prawnego. Prawo pierwokupu Agencji na podst. art. 3 ust. 4 ustawy z dnia 11 kwietnia 2003 r., jak też prawo wykupu wskazane w art. 4 tej ustawy przysługuje Agencji w przypadku przeniesienia własności nieruchomości o powierzchni nie mniejszej niż 5 ha, w pierwotnym tekście ustawy powierzchnia ta wynosiła 1 ha. Projektowany obowiązek pośrednictwa Agencji organizowania przetargu do sprzedaży nieruchomości rolnej o powierzchni poniżej 1 ha wydaje się niezasadny; będzie powodował nadmierną biurokrację i pomnażanie kosztów. Słusznie wcześniej było podnoszone, że cel ustawy, jakim jest kształtowanie ustroju rolnego nie uzasadnia objęciem ustawą gruntów, które ze względu na zbyt mały obszar nie tworzą gospodarstwa rolnego w rozumieniu regulacji o podatku rolnym. ${ }^{31}$ Na podstawie decyzji Prezesa Agencji Nieruchomości Rolnych z powodu koniczności analizowania ok. 75 tys. umów rocznie, Agencja zrezygnowała z przysługującego jej prawa pierwokupu i wykupu w odniesieniu do nieruchomości o powierzchni poniżej 1 ha. Jednak jest to interpretacja nie znajdująca potwierdzenia $\mathrm{w}$ przepisach ustawy przed jej zmianą. ${ }^{32}$

Pozytywnie można ocenić zamieszczenie autonomicznego określenia osób, jakie należy uznać za osobę bliską na potrzeby projektowanej ustawy. Z kręgu została wyłączona kategoria osób pozostających z sobą w faktycznym stałym pożyciu. Bezsprzecznie wywoła to sprzeciw osób żyjących w związkach nieformalnych z powołaniem się na ograniczanie ich praw. Jednak po wejściu w życie ustawy o kształ-

30 Zob. uzasadnienie projektu ustawy.

31 Z. Truszkiewicz, Przeniesienie własności..., op. cit., cz. I, s. 58-59; K. Stefańska, Pojęcie gospodarstwa rodzinnego w ustawie o kształtowaniu ustroju rolnego, „Studia luridica Agraria” 2005, t. V, s. 188 i n.

P. Czechowski, P. Wieczorkiewicz, Problemy ingerencji prawnej w swobodę obrotu nieruchomościami rolnymi w ustawie o kształtowaniu ustroju rolnego i jej wpływ na interpretację ustawodawstwa krajowego, „Studia luridica Agraria” 2005, t. V, s. 37 i lit. tam cytowana. 
towaniu ustroju rolnego $\mathrm{w}$ doktrynie krytycznie przyjęto odesłanie do przepisów ustawy o gospodarce nieruchomościami, wskazując, że pojęcie faktycznego pożycia jest elastyczne i może być przyczyną łatwego obchodzenia przepisów ustawy przez cudzoziemców. ${ }^{33}$ Natomiast nie został uwzględniony postulat, aby także zięć i synowa korzystali ze statusu osoby bliskiej, ze względu na to, że w obrocie rolnym są najczęściej nabywcami nieruchomości wraz z dziećmi zbywcy. ${ }^{34} \mathrm{~W}$ praktyce wywołuje to sytuacje, które można określić jako groteskę. Przy ścisłym stosowaniu się do wymogów ustawy najpierw jest zawierana umowa np. darowizny na rzecz syna lub córki, ze względu na to, że są to osoby bliskie w rozumieniu art. 4 pkt 13 ustawy o gospodarce nieruchomościami wyłączone jest prawo wykupu Agencji Nieruchomości Rolnej z art. 4 ustawy o kształtowaniu ustroju rolnego. Następnie jest zawierana druga umowa, na podstawie której syn lub córka przenoszą udział we współwłasności darowanej nieruchomości na rzecz współmałżonka albo też zawierają umowę majątkową małżeńską. Ponownie z powołaniem się na art. 4 ust. 4 lit. b wyłączone jest prawo wykupu. Z pewnością konieczność zawarcia dwóch umów, aby osiągnąć cel, jakim jest objęcie nabytej nieruchomości majątkiem wspólnym małżonków nie wzmacnia szacunku do obowiązującego prawa.

Do projektu zostało przeniesione prawo pierwokupu przysługujące dzierżawcy (art. 18). Służy ono realizacji celu, jakim jest poprawa struktury obszarowej gospodarstwa. ${ }^{35}$ Proponowane zmiany w odniesieniu do obecnej regulacji obejmują wyłączenie tego prawa, gdy przeniesienie własności nieruchomości rolnej będzie następować na rzecz osoby bliskiej, Skarbu Państwa lub jednostki samorządu terytorialnego. Niestety projekt nie uwzględnia zgłaszanych w doktrynie zastrzeżeń co do obecnego brzmienia przepisu, nieścisłości co do użytych określeń (,,wykonywanie umowy dzierżawy”, a w innym miejscu „trwania umowy dzierżawy”). ${ }^{36}$ Wymóg prawidłowej legislacji jednak powinien być przestrzegany, a zgłaszane wątpliwości co do użytych sformułowań uwzględnione.

Projektodawca przewidział także kontrowersyjne prawo określane jako prawo wykupu czy prawo nabycia przysługujące Agencji Nieruchomości Rolnych (art. 17) w przypadku, gdy przeniesienie własności rolnej lub jej części nastąpi w wyniku zawarcia umowy innej niż umowa sprzedaży. Szerzej zostało ujęte wyłączenie stosowania prawa wykupu przez Agencję ze względu na podmiot, na rzecz którego zbywca przeniósł własność nieruchomości rolnej. Oprócz umowy z następcą, Agencja nie będzie mogła skorzystać z prawa wykupu, gdy nabywcą będzie osoba, co do której wyłączone jest pośrednictwo Agencji przy sprzedaży nieruchomości. Można uznać, że każde ograniczenie tego prawa jest dobrym rozwiązaniem. Prawo wykupu barchomości rolnej..., op. cit., cz. I, s. 67.

A. Lichorowicz, Instrumenty..., op. cit., s. 406-407.

S. Prutis, Ksztaltowanie..., op. cit., s. 173.

E. Gniewek, Obowiązki notariusza..., op. cit., s. 34 . 
dzo mocno ingeruje w uprawnienia właściciela. Jest ono powszechnie krytykowane w piśmiennictwie. ${ }^{37}$ Zgłaszane uwagi dotyczyły też wątpliwości co do zgodności z Konstytucją. Jednak Trybunał Konstytucyjny w wyroku z dnia 18 marca 2010 r. ${ }^{38}$ uznał art. 4 za zgodny z Konstytucją.

W uzasadnieniu projektu zostało stwierdzone, że Agencji przy wykorzystaniu prawa wykupu będzie realizowała politykę rolną państwa w zakresie poprawy struktury agrarnej. Nie pozostawia wątpliwości cel wprowadzenia do ustawy z 2003 r. nowego, nieznanego wcześniej polskiemu ustawodawstwu mechanizmu. Jest nim „uszczelnienie obrotu”, skuteczne zapobieganie nabywaniu nieruchomości rolnych przez cudzoziemców, w sytuacji gdy do przeniesienia własności nieruchomości rolnej dochodziłoby przy wykorzystaniu innych umów niż umowa sprzedaży. ${ }^{39}$ Prawo wykupu nie jest skutecznym mechanizmem kształtowania ustroju rolnego, poprawy struktury obszarowej, nie wypełnia funkcji zapobiegania nadmiernej koncentracji nieruchomości rolnych. Liczba dokonywanych wykupów przez Agencję Nieruchomości Rolnych jest niewielka. ${ }^{40}$

Ponownie należy zaznaczyć, że w projekcie w postanowieniach odnoszących się do prawa wykupu (art. 17) nie zdecydowano się na usunięcie zgłaszanych w doktrynie niejasności co do praktycznego stosowania tego prawa w obrocie. Wątpliwości dotyczą tak podstawowych kwestii, jak rodzaj umowy przenoszącej własność nieruchomości rolnych, co do których powinno mieć zastosowanie prawo wykupu oraz tego, czy ma to być umowa warunkowa. ${ }^{41}$

Mankamentem projektu jest brak regulacji odnoszącej się do obrotu mortis causa. Nie ma postanowień regulujących przejście własności nieruchomości rolnych na podstawie testamentu ani zapisu windykacyjnego. Na podst. art. $981^{1} \S 2$ pkt 3 przedmiotem zapisu windykacyjnego może być gospodarstwo rolne. Należy pamiętać, że zapisobierca windykacyjny staje się właścicielem zapisanego mu w testamencie notarialnym gospodarstwa rolnego z chwilą śmierci spadkodawcy. Wydaje się, że prawo wykupu, o ile nadal zostanie utrzymane, powinno mieć zastosowanie przy zapisie windykacyjnym.

Pozytywnie należy się odnieść do zamieszczenia w projekcie postanowień, jakie mają przeciwdziałać nieracjonalnym podziałom gospodarstw rolnych. Podobnie

Zob. jedynie przykładowo: A. Lichorowicz, Instrumenty..., op. cit., s. 415 i n.; S. Prutis, Kształtowanie..., op. cit., s. 177 i n.; A. Stańko, Zakres przedmiotowy art. 4 ustawy o kształtowaniu ustroju rolnego, „Studia luridica Agraria" 2005, t. IV, s. 112 i n.; J. Matys, Niektóre problemy umowy dożywocia na tle ustawy o kształtowaniu ustroju rolnego, „Nowy Przegląd Notarialny” 2005, nr 1, s. 30 i n. K 8/08, OTK-A 2010, nr 3, poz. 23.

39 A. Lichorowicz, Instrumenty..., op. cit., s. 415.

40 Zob. S. Prutis, Kształtowanie..., s. 180. W informacji o realizacji ustawy o kształtowaniu ustroju rolnego - wybrane zagadnienie nie ma podanej liczby dokonanych przez Agencję wykupów, zob. http://www.anr.gov.pl/web/guest/251 A. Lichorowicz, Instrumenty..., op. cit., s. 415; E. Gniewek, Obowiązki notariuszy..., op. cit., s. 38 i n. 
należy ocenić wprowadzenie minimalnej normy obszarowej. W obecnej ustawie nie ma takiej regulacji. A. Lichorowicz wskazywał, że jest to jedna z najbardziej istotnych jej luk, która rzutuje na brak skuteczności w odniesieniu do poprawy struktury gruntowej kraju, co stanowi przecież jeden z głównych celów. ${ }^{42}$ Jednak należy rozważyć, czy projektowane ograniczenia zakazu podziału gospodarstw rolnych, które ujęte są szeroko, nie zniwelują sensu jego wprowadzenia, a co za tym idzie także spowodują, że cel projektu ponownie zostanie jedynie założeniem nie mającym odzwierciedlenia w praktyce obrotu.

Projektodawca posługuje się sformułowaniem ,zbycie nieruchomości rolnej lub jej części". Należy pamiętać, że przedmiotem obrotu jest zawsze nieruchomość jako całość, nie można zbyć części nieruchomości, która nie została wydzielona jako działka ewidencyjna. ${ }^{43}$

Skrótowe omówienie złożonego do Sejmu projektu ustawy o kształtowaniu ustroju rolnego, autorstwa PSL pokazuje, że planowane rozwiązania, bazujące w dużej części na obecnej regulacji, nie zapewnią skutecznej realizacji celów zakreślonych w art. 1 projektu. Jak już miało to miejsce w 2003 r. główną przyczyną projektowanej ustawy nie jest potrzeba wprowadzenia skutecznych mechanizmów kształtowania ustroju rolnego, a przeciwdziałanie możliwości nabywania nieruchomości rolnych przez cudzoziemców. Zdecydowanie negatywnie należy ocenić sytuację, w której projektodawca nie uwzględnia zgłaszanych przez przedstawicieli nauki prawa rolnego uwag odnoszących się do obecnego stanu prawnego oraz sugestii wskazujących możliwość poprawy istniejących nieścisłości. W konsekwencji nadal aktualne są słowa A. Lichorowicza wypowiedziane w 2005 r., że problem nowoczesnej, całościowej regulacji w zakresie oddziaływania na struktury gruntowe jest nadal otwarty. ${ }^{44}$

A. Lichorowicz, Instrumenty..., op. cit., s. 391, 429; idem, Regulacja..., op. cit., s. 13.

43 Z. Truszkiewicz zwraca uwagę na konstrukcyjnie wadliwe pojęcie „nieruchomość rolna”. Słusznie zaznacza, że przedmiotem obrotu własnościowego jest zawsze nieruchomość, bez względu na rodzaj użytków wchodzących w skład danej nieruchomości. Nieruchomość może obejmować zarówno użytki rolne oraz inne użytki, wówczas powstaje zagadnienie, która z nieruchomości jest nieruchomością rolną. Zob. szerzej Z. Truszkiewicz, Regulacja prawna obrotu nieruchomościami rolnymi między żyjącymi - uwagi de lege ferenda, „Studia luridica Agraria” 2010, t. VIII, s. 35; zob. też B. Wierzbowski, Pojęcie nieruchomości rolnej w prawie polskim, „Studia luridica Agraria" 2010, t. IV, s. 95 i n. 


\section{NEW ACT OF SHAPING AGRICULTURAL SYSTEM \\ - REMARKS TO THE POLISH PEOPLE'S PARTY DRAFT BILL}

Keywords: property right, agricultural lands, Agricultural Property Agency

The draft bill on shaping of the agricultural system which is to repalce the current version of the Act of 11 April 2013 was submitted to the Parliament by Polish People's Party in in July 2014. Beyond aims listed in the article 1 of the Bill, undoubtedly it is also to create more effective than the present ones mechanisms counteracting the possibility of acquisition of agricultural lands by foreigners. Planned arrangements are partly based on the current Act of 2003 and there are also new instruments proposed, such as obligatory mediating of Agricultural Property Agency in the sales of every agricultural property irrespectively of its size, as well as prohibition of sale and encumbrance of the agricultural property purchased by tender for 10 year of the date of purchase. The proposals are ill-conceived from the agricultural activity practice point of view and the limitations go far beyond the nature of property right, which is contrary to the Constitution. 